\title{
Arkadiusz Wagner
}

Uniwersytet Mikołaja Kopernika w Toruniu, Toruń, Polska

wagner@umk.pl

ORCID 0000-0001-9525-0579

\section{„Częścią dla ozdoby, częścią aby poznano czyia to księga iest”. Refleksje po lekturze artykułu recenzyjnego Marii Cubrzyńskiej-Leonarczyk}

\begin{abstract}
„Partly for decoration, partly to made known whose the book is". Reflection after reading the review by Maria Cubrzyńska-Leonarczyk

The article is a response to the extensive review by Maria Cubrzyńska-Leonarczyk concerning the first Polish monograph of superexlibris from the Middle Ages to the half of the $17^{\text {th }}$ century, which I published in 2016. Primarily, it contains rectifications of numerous concealments and mistakes that the Reviewer has made in her article. According to the author of the response to the review many of them are the consequence of a doctrinaire and anachronistic interpretation of the notion of superexlibris, which origins from the opinions of Kazimierz Piekarski (1920s - 1930s). Moreover, the author points out a range of interesting and inspiring remarks and discoveries of the Reviewer.
\end{abstract}

Key words: books owners' marks, superexlibris (supralibros) - different categories, so-called heraldic superexlibris (coat of arms), so-called inscription superexlibris, bookbinding, so-called tegumentology (book bindings studies) .

Słowa kluczowe: znaki własnościowe książki, superekslibris - różne kategorie, superekslibris herbowy, superekslibris napisowy, introligatorstwo, tegumentologia (oprawoznawsto).

„Z Badań nad Książką i Księgozbiorami Historycznymi” - Udział zagranicznych recenzentów w ocenie publikacji; Stworzenie anglojęzycznej wersji wydawniczej publikacji; Digitalizacja tomów archiwalnych rocznika w celu zapewnienia otwartego dostępu do nich przez Internet oraz wdrożenie i utrzymanie cyfrowej platformy redakcyjnej - zadanie finansowane w ramach umowy nr 653/P-DUN/2019 ze środków Ministra Nauki i Szkolnictwa Wyższego przeznaczonych na działalność upowszechniającą naukę. 
W tomie 11. (za 2017 r.) niniejszego periodyku ukazał się artykuł recenzyjny Marii Cubrzyńskiej-Leonarczyk napisany „na marginesie lektury” monografii mojego autorstwa pt. Superekslibris polski. Studium o kulturze bibliofilskiej i sztuce od średniowiecza do połowy XVII wieku (Torun 2016)․ Owa długoletnia pracowniczka Biblioteki Uniwersyteckiej w Warszawie, a jednocześnie badaczka książkowych znaków własnościowych, podjęła się niemałego trudu analizy obszernej - bo niemal sześciusetstronicowej - książki. Jej wynikami podzieliła się w adekwatnie rozległym, bo osiemnastostronicowym, tekście, zaopatrzonym w niewielki aparat przypisów i bibliografii. Zawiera on nie tylko dokładną charakterystykę poszczególnych części książki, ale też liczne spostrzeżenia i uwagi, nierzadko o charakterze polemicznym.

Okoliczności te, wraz z szacunkiem jakim od około dwudziestu lat - czyli od początku mojej aktywności publikacyjnej - darzę badawcze poczynania Recenzentki, sprawiają, że za swą powinność uznałem ustosunkowanie się do Jej tekstu. Było to tym bardziej uzasadnione, że wiele stwierdzeń Recenzentki wymaga komentarza tudzież sprostowania. Szereg innych uważam za nietrafione, a nawet całkowicie błędne. Jeszcze inne noszą według mnie znamiona przemilczenia określonych faktów, a w konsekwencji - recenzenckiej manipulacji. Podkreślić jednak trzeba, że sąsiadują one z passusami, które wzbogacają zawartość zrecenzowanej monografii. Wyraz temu dałem zresztą w tytule niniejszego tekstu, w którym posłużyłem się niezwykle interesującym cytatem z przywołanego przez Recenzentkę - a nieznanego mi - źródła.

Pierwszą partię tekstu Recenzentki zajmuje charakterystyka koncepcji oraz struktury treściowej monografii. Przypomnijmy, że zgodnie z tytułem, a zwłaszcza założeniami wyartykułowanymi we Wstępie, objęła ona ziemie Królestwa Polskiego (tamże wyszczególniono: Małopolskę, Wielkopolskę, Mazowsze i Ruś Czerwoną oraz Prusy Królewskie i Warmię) oraz Wielkie Księstwo Litewskie, co uzasadniają „,pogłębiające się w ciągu XVI i XVII wieku więzi polityczne i kulturowe" między nim a Koroną ${ }^{2}$. Z podobnych przyczyn włączono do monografii Prusy Książęce, natomiast zrezygnowano z ,analizy superekslibrisu w księstwach pomorskich oraz w księstwach śląskich, które były nie tylko poza granicami Polski, ale już od schyłku średniowiecza prezentowały niemiecką kulturę bibliofilską"3. Nadmienię jednak, że oba regiony wprzęgnięto w charakterystykę superekslibrisu w Europie, obejmującą nie

1 M. Cubrzyńska-Leonarczyk, «Najszlachetniejszy ze wszystkich znaków własnościowych». Na marginesie lektury ksiązki Arkadiusza Wagnera Superekslibris polski. Studium o kulturze bibliofilskiej i sztuce od średniowiecza do połowy XVII wieku, Toruń 2016, „Z Badań nad Książką i Księgozbiorami Historycznymi" 2017, t. 11, s. 453-470.

2 A. Wagner, Superekslibris polski. Studium o kulturze bibliofilskiej i sztuce od średniowiecza do połowy XVII wieku, Toruń 2016, s. 12.

3 Tamże. 
tylko kulturalne centra, jak Italia i Francja, ale też kraje przyległe do Rzeczypospolitej. Niestety, Recenzentka uznała, iż „obrany zasięg terytorialny pozbawia nas [podkreślenie: A.W.] wiedzy o znakach pomorskich, a przede wszystkim śląskich"4, tak jakby w monografii jednego z aspektów historii Polski była ona czytelnikom należna. Swój niedosyt, niczym w rodzimej literaturze historycznej z lat 50. i 60. XX w., uzasadniła żywością kontaktów Śląska z Akademią Krakowską w XVI w., a ponadto powiązaniami gospodarczymi, handlowymi, finansowymi czy też rodowymi z państwem polskim. Przyjmując taki punkt widzenia, należałoby jednak postulować włączenie do zasadniczej treści monografii wszystkich krajów we władaniu Habsburgów austriackich (zwłaszcza Królestwa Czeskiego i Moraw), przynajmniej części księstw niemieckich, a już na pewno ośrodka norymberskiego. Wszak zwłaszcza to miasto $\mathrm{w}$ interesującym nas okresie odznaczało się wieloaspektowymi powiązaniami ze stolicą Polski (włącznie z szeroko rozumianą kulturą książki). Być może satysfakcję Recenzentki zyskałoby też uwzględnienie Księstwa Mediolanu, pochodzące stamtąd oprawy wywarły bowiem przemożny wpływ na kształtowanie się renesansowego introligatorstwa krakowskiego (w tym i tradycji superekslibrisu). Na uzasadnienie swego stanowiska Recenzentka przytoczyła dwa superekslibrisy śląskich bibliofilów z XVI-pocz. XVII w., na które „wystarczy popatrzeć” by dostrzec stylistykę „łączącą się z kulturą Królestwa Polskiego"5. Co ciekawe, jednym z nich jest superekslibris Georga Scultetusa, który znalazł się w mojej monografii na s. 86 i il. 17 w kontekście Tła europejskiego. Jego też pozwolę sobie obrać za argument w odpowiedzi. Jeśli bowiem Recenzentka widzi w tym dziele związki z polską kulturą, to na równi winna je widzieć w renesansowej kulturze włoskiej i francuskiej (z których wywodzi się sam rollwerk - ornament zwijany), jak i niemieckiej (w której superekslibrisy z rollwerkowymi kartuszami herbowymi i owalnymi otokami/obramieniami zyskały szczególną popularność).

W dalszej części tekstu Recenzentka dzieli się z czytelnikami żalem, że „Autor nie uwzględnił [w monografii] całej epoki staropolskiej”. Ustosunkowując się do tego uczucia wypada mi chyba stwierdzić, iż podobnym żalem należałoby obdarzyć wszelkie monografie zjawisk średniowiecznych (że nie objęły epoki nowożytnej), czy też nowożytnych (że nie objęły XIX-XXI w.). Dodam do tego, że wbrew przypuszczeniom Recenzentki moja rezygnacja z analizy polskiego superekslibrisu 2 połowy XVII i całego XVIII w. nie była podyktowana „nikłym stanem przebadania zbiorów dawnych polskich opraw"6. Akurat bowiem rodzimych superekslibrisów w tym okresie powsta-

4 M. Cubrzyńska-Leonarczyk, dz. cyt., s. 454.

Tamże.

6 Dz. cyt., s. 455 (cytat zaczerpnięty ze s. 35 recenzowanej monografii). 
ło relatywnie niewiele, co sprzyjałoby ich szybkiej, badawczej eksploracji. Jeszcze lepiej przeanalizowane są XVIII-wieczne ekslibrisy, które efektownie dopełniają obraz przemian w sferze dawnych „księgoznaków”. Zasadniczym powodem mojej rezygnacji było więc uznanie owego - ponad półtorawiekowego - okresu za osobną erę w dziejach polskiej kultury bibliofilskiej. Tym samym, korzystając z prawa przysługującego każdemu badaczowi, dokonałem wyboru tematu monografii na rzecz epoki ważniejszej i bogatszej w zjawiska na polu superekslibrisu, aniżeli dekady po potopie szwedzkim, era saska, a nawet czasy stanisławowskie. Niemniej oczywiście zgadzam się z Recenzentką, że i one mają w sobie ogromny potencjał badawczy, który może kiedyś - na zasadzie kontynuacji raz podjętego zagadnienia - zdecyduję się wyzyskać. A jeśli nie ja, to inny badacz. Tak czy inaczej, akcent w ocenie dokonanej przez Recenzentkę winien być raczej położony na to, jak rozległy okres objęto zainteresowaniem w monografii, a nie jakiego okresu nim nie objęto.

W dalszej części recenzji jej Autorka dotyka kwestii początków badań nad polskim superekslibrisem. Odnosząc się do odnotowanej przeze mnie daty pierwszej wzmianki o charakterze naukowym, jaka znalazła się w słynnym dziele Jana Daniela Janockiego, Specimen Catalogii... z 1752 r., wskazała na źródło o niemal 100 lat starsze. Jest nim Kazanie wtore... Szymona Starowolskiego, wydane w Krakowie w 1645 r. Historyczna wartość tych słów skłania, by i w tym miejscu je przytoczyć: ,„[...] na kochanych księgach naszych, które każemy drogo oprawić, rozkazujemy zaraz i herb na nich położyć, częścią dla ozdoby, częścią aby poznano czyia to księga iest" ". Zostawiając ich analizę na inną okazję, podkreślić należy, iż odkrycie Recenzentki skłaniałoby do przyjrzenia się innym ówczesnym tekstom literackim, w tym zwłaszcza panegirykom i stemmatom. W nich bowiem znajdować się mogą dalsze exempla obecności ksiąg z herbami w świadomości staropolskich elit kulturalnych i politycznych. O tym, że byłyby to poszukiwania owocne, zdają się świadczyć ówczesne portrety malarskie i graficzne (w tym książkowe) polskich nobiles, wśród których - może nie tak często jak przedmioty dewocji czy zegary kaflowe - dopatrzyć się można oprawnych ksiąg.

Pewną osobliwością tekstu Recenzentki jest krytyka mojego - raz zbyt chłodnego, raz zbyt gorącego - stosunku do dorobku niektórych badaczy superekslibrisów. Jako, że krytyka ta odbiega od mych faktycznych intencji, czuję się zmuszony do niej odnieść. Jak pisze Recenzentka: „Autor, zdaje się, nie w pełni docenia zasługi wybitnego uczonego Kazimierza Piekarskiego"s. Otóż spieszę donieść, że wbrew owym domysłom, bez żadnej wątpliwości

7 Tamże (za: Szymon Starowolski, Kazanie wtore o nowym oswieciniu świata przez Marya, iako przez ksiegge iaka cudownie pisana, [w:] tegoż, Swiatnica Panska Zamykająca w sobie Kazania Na Vroczystosci Swiąt Całego Rokv..., Kraków 1645, s. 602).

8 M. Cubrzyńska-Leonarczyk, dz. cyt., s. 456. 
i w całej pełni doceniam jego zasługi(!). Chyba najdobitniejszym tego dowodem jest liczba odwołań do ustaleń tego badacza, zawarta w Indeksie osób. Co więcej, na s. 17, z której Recenzentka wypreparowała rzekome dowody jego niedocenienia, podkreślam, iż „zawdzięczamy [mu] skodyfikowanie podstawowego zasobu pojęciowego oraz zainicjowanie systematycznego rejestrowania obiektów"9. Podtrzymuję natomiast stanowisko, że liczba publikacji Piekarskiego w zakresie superekslibrisu jest stosunkowo niewielka, i to niekoniecznie z powodu wybuchu II wojny światowej oraz śmierci badacza w 1944 r. (jak chciałaby wyjaśniać Recenzentka). Unaocznia to choćby sztandarowe dzieło Piekarskiego: zeszyt z 40 przerysami pt. Superexlibrisy polskie..., wydany w 1929 r., z jednoczesną zapowiedzią cokwartalnego pojawiania się kolejnych zeszytów, aż do liczby 600 tablic. Mimo - zaakcentowanego przeze mnie entuzjazmu uczonego ${ }^{10}$, do wybuchu wojny przedsięwzięcie ograniczyło się do wspominanej jednej teki.

Powodem zaskoczenia Recenzentki jest „nader wysoka” ocena katalogu pt. Oprawy polskie, wydanego w 1987 r. pod auspicjami m.in. Biblioteki Narodowej ${ }^{11}$. Ma ku temu osobiste powody, była bowiem surową recenzentką tegoż wydawnictwa (chociaż recenzji nie odnotowałem w Wybranej bibliografii monografii, uspokajam Autorkę: jej tekst znam dobrze). Mimo tego, winna Ona dostrzec różnicę naszych punktów widzenia na tę publikację. Dla mnie bowiem niezaprzeczalnym walorem katalogu jest upublicznienie informacji o szeregu bezcennych dzieł z superekslibrisami w zbiorach Biblioteki Narodowej (choćby Mikołaja Reja czy Opalińskich na unikatowej oprawie à la fanfare z 1644 r.). Ów walor zachował on zresztą do dziś (w każdym razie do czasu opublikowania monografii), wobec faktu, iż w narodowej książnicy wciąż niedostępny jest katalog proweniencji, nie mówiąc o katalogu opraw. W konsekwencji wszelkie błędy i uchybienia, jakie swego czasu wytknęła tej publikacji Recenzentka okazały się dla mnie drugorzędne wobec wagi zawartych w nim danych o cymeliach introligatorstwa i superekslibrisu.

Podobna rozbieżność między mną a Recenzentką tyczy się stosunku do katalogów superekslibrisów autorstwa Marii Sipayłło (Warszawa 1988) i... Marii Cubrzyńskiej-Leonarczyk (Warszawa 2001). Mimo niedociągnięć edytorskich i koncepcyjnych (np. reprodukcje jedynie drobnych fragmentów opraw z superekslibrisami, tradycyjne retusze fotograficzne, niekiedy zniekształcające ich realny wygląd, czy też nieuwzględnienie superekslibrisów napisowych $)^{12}$ obie

\footnotetext{
A. Wagner, dz. cyt., s. 17.

Tamże, s. 17.

M. Cubrzyńska-Leonarczyk, tamże.

2 Zob. np.: M. Komza, Maria Cubrzyńska-Leonarczyk, Polskie superekslibrisy XVI-XVIII wie$k u$ w zbiorach Biblioteki Uniwersyteckiej w Warszawie. Centuria druga, Warszawa: Biblioteka Narodowa, 2001 [...]-Recenzja, „Roczniki Biblioteczne” 2001, t. 45, s. 298-302.
} 
publikacje odegrały - i wciąż odgrywają - ważną rolę w rodzimych badaniach nad książkowymi znakami własnościowymi. Doprawdy więc nie wiem, czy owa deprecjacja wydawnictw macierzystej placówki Recenzentki jest wyrazem Jej kokieterii czy frustracji. Reasumując, krytycyzmowi Recenzentki wobec tych i szeregu innych - docenionych przeze mnie - publikacji (np. Rudolfa Kotuli, Franciszka Pilarczyka), należałoby chyba przeciwstawić mądrość ludową, w myśl której „na bezrybiu i rak ryba”. Wynika to z prostej przyczyny: wobec dramatycznego ubóstwa literatury dotyczącej dawnego polskiego superekslibrisu i introligatorstwa, nawet skromne i nie wolne od błędów wydawnictwa mają wymierną wartość naukową. Dodam, że szereg z nich dostarcza informacji o dziełach unicestwionych podczas I i II wojny światowej.

Rozdziałem monografii, któremu Recenzentka poświęciła sporo uwagi i okrasiła szeregiem dosadnych stwierdzeń jest ten dotyczący Zakresu pojęcia [superekslibris]. Radykalne różnice naszych poglądów na niektóre kwestie mają, według mnie, swe źródło w doktrynersko rozumianych przez Recenzentkę słowach K. Piekarskiego, jakoby superekslibris był „o wiele szlachetniejszą" formą znaku własności książki, niż „później dopiero szerzący się exlibris”13. Zanim odniosę się do paru wysoce dyskusyjnych poglądów Recenzentki, podzielę się pewną refleksją. Otóż jako naukowiec i bibliofil nie potrafiłbym rozstrzygnąć czy faktycznie superekslibris jest „szlachetniejszy” od swego graficznego odpowiednika. Mimo szczerej fascynacji tą kategorią księgoznaku, więcej znam bowiem ekslibrisowych sztychów, o których z zachwytem rzekłbym, że to arcydzieła o wyrafinowanej kompozycji i maestrii wykonania. Co więcej, swym pięknem emanują one zarówno in situ, czyli wewnątrz ksiąg, jak i w kolekcjonerskiej tece. Superekslibrisy zaś najczęściej ujawniają swój powab w otoczeniu introligatorskiej dekoracji okładzin; wyciśnięte osobno przeważnie wiele tracą ze swej okazałości i dostojeństwa. W konsekwencji uważam więc, że zamiast trwać z uporem przy zamierzchłej opinii, rozsądniej byłoby przyjąć, że zarówno sztuka superekslibrisu jak i ekslibrisu ma swe arcydzieła i „tandetę".

Wracając do meritum recenzji, jej Autorka przygląda się mojej propozycji rozszerzenia zwięzłej definicji superekslibrisu o liczne rodzaje znaków i napisów własnościowych ukazywanych na zewnątrz okładzin (wymieniam je w tym samym akapicie). Choć niekiedy mają one skromniejszą formę niż klasyczne księgoznaki herbowe, to podporządkowane są tej samej funkcji oznaczania własności woluminu. $Z$ tegoż stwierdzenia Recenzentka wyciąga błędny

13 Cytaty za: K. Piekarski, Superexlibrisy polskie od XV do XVIII wieku. Z. 1, Kraków 1929, s. 1 nienum. Recenzentka przytacza podobne słowa, zaczerpnięte z innego tekstu Piekarskiego, O superexlibrisie polskim, [w:] Katalog wystawy pięknej ksiażki polskiej urządzonej z powodu IV. Zjazdu Bibliotekarzy Polskich w Warszawie, 31 maja - 15 czerwca, Warszawa 1936, s. 29, cyt. za: M. Cubrzyńska-Leonarczyk, dz. cyt., s. 453-454, 458. 
wniosek, jakobym „wszystko co znajduje się na zewnętrznej części okładzin, a ma coś wspólnego [podkreślenie A.W.] z introligatorskim «oznaczaniem własności księgi» [uważał za] superekslibris”. Konkluzja ta stanowi asumpt do krytyki, w ramach której zarzuca mi m.in. ograniczenie się do perspektywy etymologicznej i funkcjonalnej kosztem perspektywy historycznej i estetycznej (w tej drugiej Recenzentce zapewne chodzi znowu o kryterium wizualnej „szlachetności” superekslibrisów). Przeciw mojemu stanowisku świadczyć mają ,pozaintroligatorskie pośrednie dowody posiadania danego woluminu” w postaci pomalowanych grzbietów, które „można uznać za znaki własnościowe, ale nie zawsze będą to superekslibrisy" ${ }^{14}$. Ustosunkowując się do tego poglądu: po pierwsze - w monografii niejednokrotnie omawiam superekslibrisy malowane, ale nigdy nie pomalowane grzbiety jako znaki własnościowe; po drugie - chociaż faktycznie pomalowane grzbiety, a zwłaszcza znajdujące się na nich (czasami też malowane) sygnatury, mogą służyć jako „pozaintroligatorskie pośrednie dowody własności księgi" (więcej: mogą mieć status corpus delicti $)^{15}$ to nie mogą być postrzegane jako znaki własnościowe. Dlaczego? Bo - pozwolę sobie przypomnieć definicję z EWOK - sygnatura książki nie jest znakiem własnościowym, ale „znakiem miejsca obiektu bibliotecznego"16. Zresztą, w librariach klasztornych podobną rolę pełniły różne barwy malunków na grzbietach: informowały o rozlokowaniu określonych działów tematycznych księgozbioru ${ }^{17}$. No chyba, że obok sygnatury widnieje np. malowane godło zakonu - czyli superekslibris malowany.

W kontekście rozmaitych, nietypowych form superekslibrisów odnotować należy, że Recenzentka zapomniała, bądź nie chciała pamiętać, o wielokrotnie akcentowanym przeze mnie problemie quasi-superekslibrisów. W największym skrócie są to znaki książkowe, które wymykają się klasycznej definicji superekslibrisu. A wymykają, bo przede wszystkim nie pełnią funkcji znaku własnościowego sensu stricto (Recenzentkę zachęcam do ponownej lektury stosownych fragmentów monografii, które rzucają światło na różnorakie definicyjne imponderabilia). W tym samym akapicie Recenzentka porusza problem

\footnotetext{
14 M. Cubrzyńska-Leonarczyk, dz. cyt., s. 458.

15 Przekonałem się o tym przed laty jako biegły sądowy w słynnej sprawie Stanisława Sz. Według dostępnych mi informacji książki wykradane przez tę osobę z jednej z bibliotek kościelnych były pozbawiane opraw m.in. dlatego, że ich grzbiety były pomalowane i oznaczone sygnaturami. Te zaś, po wprowadzeniu ksiąg na rynek antykwaryczny, mogły być skojarzone z ową biblioteką.

16 Encyklopedia Wiedzy o Książce, red. zbiorowa, Wrocław-Warszawa-Kraków 1971, szp. 2255.

17 Na marginesie warto wspomnieć, że w przypadku niektórych dawnych bibliotek grzbiety (a nawet całe oprawy) ksiąg malowano również ze względów estetycznych: ujednolicony kolor wszystkich woluminów stojących na regałach stanowił element wystroju wnętrza. Niekiedy, zamiast tej-w sumie prymitywnej - metody, decydowano się na oklejanie grzbietów wszystkich woluminów $\mathrm{w}$ jednakowo zdobione skóry.
} 
nalepek bibliotecznych na wewnętrznych stronach opraw. Jako że postrzegam go tu jako drugorzędny, stwierdzę tylko, że stał się on przedmiotem mojej refleksji badawczej w dwóch artykułach ${ }^{18}$.

Kwestią budząca w paru miejscach zdecydowany opór Recenzentki są superekslibrisy napisowe. Przypomnijmy, że pod tym pojęciem rozumiem charakterystyczną i liczną grupę księgoznaków, w których ograniczono się do pełnych imion i nazwisk bądź ich skrótów (jako sygle i suspencje), często z towarzyszącymi im skrótami tytulatury bibliofila i datami wykonania oprawy. Szczerze mówiąc, nie jestem zaskoczony postawą Recenzentki, od wielu już lat obserwuję bowiem determinację z jaką pracowniczki Gabinetu Starych Druków BUW odmawiają bytu tej kategorii księgoznaków. Zamiast tego, w wydawanych przez tę placówkę publikacjach, stosują słowną ekwilibrystykę, że wspomnę o „tłoczeniach literowych” czy „własnościowych oznaczeniach literniczych" (swoją drogą: a co z oznaczeniami liczbowymi?) ${ }^{19}$. Dodam, że jest ona nie tylko mało komunikatywna - by nie rzec: enigmatyczna - ale też metodologicznie kłopotliwa. Kurczowe trzymanie się takiej koncepcji zmusiło bowiem M. Sipayłło i M. Cubrzyńską-Leonarczyk do eliminacji superekslibrisów napisowych z opracowanych przez nie katalogów superekslibrisów. O konsekwencjach takiego stanowiska pisałem w monografii (s. 52); tu przypomnę tylko, że ogół badaczy i miłośników ksiąg pozbawia ono wiedzy o wielu egzemplarzach znaków własnościowych, nierzadko związanych z koryfeuszami rodzimego bibliofilstwa. Wszystko zaś z powodu iście ortodoksyjnego podejścia M. Sipayłło ${ }^{20}$ i jej następczyń do niegdysiejszych - trochę idealistycznych, trochę retorycznych - słów K. Piekarskiego o „szlachetności" superekslibrisu, jako jego nienaruszalnym desygnacie. Status dogmatu badawczego zyskała dla nich także skrótowa i ogólnikowa kategoryzacja superekslibrisu, jaką K. Piekarski dokonał w 1932 r. $^{21}$ Wedle niej, dzielimy go na „superekslibrisy właściwe” i „,introligatorskie”. Co istotne, te drugie „odbijane bywają przez introligatora $\mathrm{z}$ osobna stemplami, które należały do

18 M.in. A. Wagner, Ekslibris jako dziedzina grafiki w sferze zainteresowania historii sztuki i bibliologii, [w:] Metodologia, metoda i terminologia grafiki i rysunku. Teoria i praktyka, red. J. Talbierska, Warszawa 2014, s. 100-101.

19 Dyskusję z tą osobliwą postawą pracowniczek BUW podjąłem już w tekście monografii, powołując się na konkretne teksty M. Sipayłło, M. Cubrzyńskiej-Leonarczyk, M. Czapnik i E. Bylinowej (s. 51, przyp. 61). Tam też przedstawiłem, w moim mniemaniu - proste i logiczne, argumenty przeciwko takiemu rozumowaniu. Recenzentka w swym tekście zupełnie je przemilcza.

20 Jej wykładnię M. Sipayłło zawarła w tekście pt., O metodzie badań proweniencyjnych starych druków, „Z Badań nad Polskimi Księgozbiorami Historycznymi” 1975, z. 1, s. 9-30 (tamże, na s. 22 znamienna informacja, że „mamy w BUW indeks rzeczowy ułożony według następujących haseł: Superekslibrisy polskie. Tłoczenia literowe. Exlibrisy polskie. Pieczęcie polskie [...]”). S. 380

${ }^{21}$ K. Piekarski, Książka w Polsce XV i XVI wieku, [w:] Kultura staropolska, Kraków 1932, 
zasobów jego warsztatu"22. Pozwolę więc sobie zapytać Recenzentkę: czymże są jej „własnościowe oznaczenia liternicze” (jeśli już, winno być: „literniczo-cyfrowe") jeśli nie maksymalnie zredukowaną odmianą superekslibrisu introligatorskiego? Zredukowaną o np. wyciski prostych tłoków $\mathrm{z}$ herbami tudzież otoki ornamentalno-inskrypcyjne, które - pamiętajmy o tym! - miały takie samo uniwersalne przeznaczenie, jak tłoki liternicze i przedstawiające cyfry.

Zamiast głębiej zastanowić się nad tą kwestią Recenzentka ofiarnie broni stanowiska koleżanek z BUW, podejmując polemikę z moim stanowiskiem. Jak można się domyślić, wyzyskuje do tego autorytet K. Piekarskiego, tudzież „nauk pobieranych ongiś w naukowych bibliotekach polskich”23. Służyć temu ma również zestaw argumentów, do których pozwolę się odnieść:

- wedle Recenzentki superekslibrisami nie mogą być „pojedyncze litery odbijane z oddzielnych tłoków, pozbawione wszelkich ozdób i pomysłu artystycznego"24. Zgodnie z tą optyką widzenia superekslibrisem jest tylko to, co ma ozdoby, tj. ornamenty i motywy dekoracyjne. Ja jednak chciałbym przypomnieć, że już w XVIII w., pionier nowożytnej historii sztuki, Johann J. Winckelmann, ukuł pojęcie „szlachetnej[!] prostoty", opierającej się na redukcji, czy wręcz rezygnacji z ozdób. Już choćby z tego względu (o wielu innych nie będę tu wspominać) nieporozumieniem jest odbieranie kompozycjom literniczym ,,pomysłu artystycznego". Przeciwnie, w moim - jako historyka sztuki - przekonaniu, wkomponowywanie sygli czy bardziej rozbudowanych napisów w poziome listwy między radełkowaniami jest bardzo wysmakowane w swej powściągliwości i skromności (cechy te akcentuję wobec szczególnej popularności takiej formy superekslibrisu w środowisku protestanckim, fot. 1a-b).

- na s. 458 tekstu Recenzentka zapytuje w dramatycznych słowach: „cóż jest szlachetnego w oprawie wyposażonej w pojedyncze litery (inicjały lub ich zestaw), nierzadko zresztą odbite niestarannie z przyciężkiego, czasami niezgrabnego introligatorskiego tłoka”. Na pierwszą część pytania odpowiedziałem wyżej; na drugą odpowiadam pytaniem: w jakiej cesze tłoków literniczych (rozumiem że także cyfrowych, którymi ukazywano daty) Recenzentka dostrzega ,przyciężkawość” i „niezgrabność"? Ja widzę w ich antykwowych, majuskułowych krojach naśladownictwa pięknych renesansowych czcionek drukarskich, a w niektórych przypadkach wręcz napisów epigraficznych z czasów rzymskich. Jako takie były one wyrazem wrażliwości ówczesnych introligatorów i ich

\footnotetext{
22 Tamże.

23 M. Cubrzyńska-Leonarczyk, dz. cyt., s. 458.

24 Tamże.
} 
klientów na estetykę renesansu, zgodnie z którą antykwowe litery same w sobie są ozdobą.

- na s. 460 Recenzentka odnosi się do bardziej rozbudowanych kompozycji superekslibrisów napisowych, którym poświęciłem uwagę w osobnym podrozdziale monografii. Wśród nich wspomina m.in. o osobliwych księgoznakach: Zygmunta Augusta z 1549 r. oraz Sebastiana Petrycego z 1583-84 r. Jednakże wyraźnie zastrzega, że ,przenigdy nie zaliczyłaby do tej kategorii wytłoczonych $[\ldots] \mathrm{z}$ oddzielnych tłoków introligatorskich liter bez żadnej kompozycji i sztafażu zdobniczego czy ikonograficznego" 25 . Rozumiem przeto, że Recenzentka eliminuje z kategorii superekslibrisów lub choćby quasi-superekslibrisów np. słynne inskrypcje na dolnych okładzinach Monumentów Zygmunta Augusta. Te bowiem najczęściej wyciskano z osobnych tłoków w pustym polu zwierciadła, skąpiąc im wszelkich ornamentów i wizerunków. A że poprzez te skromne środki formalne naśladowano antyczne tablice inskrypcyjne o złoconych literach i tworzono treść odwołującą się do myśli Cycerona - nie ma znaczenia: pozostają one li tylko „własnościowymi oznaczeniami literniczymi”. Swoją drogą ciekawe co sądzi Recenzentka w tej kwestii o K. Piekarskim, który owe inskrypcje na Monumentach nazywał właśnie „superekslibrisami”. A uściślając: nazywał tak gdy pisał własne przyczynki ${ }^{26}$, bo gdy w ostrych słowach recenzował katalog autorstwa R. Kotuli, faktycznie już nie ${ }^{27}$. Nadmienię, że odnoszę się do tego w monografii (s. 51, przyp. 62). Recenzentka jednak zdaje się tego nie widzieć; przypuszczam że dlatego, iż zmuszałoby to ją do demitologizacji K. Piekarskiego i jego - jak się okazuje - luźnych, badawczych dogmatów.

We fragmencie recenzji dotyczącym terminologii i kategoryzacji warto odnieść się jeszcze do czterech kwestii. Pierwsza wiąże się z superekslibrisami napisowymi wyciskanymi ze sztancy, które według Recenzentki mają w Polsce genezę XIX-wieczną. W największym skrócie odpowiadam, że mają genezę znacznie wcześniejszą. Jeśli bowiem rozumieć pojęcie „sztanca” jako

25 M. Cubrzyńska-Leonarczyk, dz. cyt., s. 459-460.

26 F. Biesiadecki, K. Piekarski, Materjały do dziejów biblioteki Zygmunta Augusta. Serja I, „Exlibris” 1924, t. 5, s. 40 (tamże określenie: „superekslibris słowny” - odnoszące się do inskrypcji na dolnych okładzinach Monumentów, oraz określenie „superekslibris herbowy” - odnoszącego się do klasycznych wizerunków herbowych na górnej okładzinie); K. Piekarski, O superexlibrisie polskim..., s. 29, nr kat. 119, 122, 166, $170 \mathrm{i}$ in. („Superexlibris [...]. Może to być napis wymieniający nazwisko właściciela”), zob. też mój komentarz: A. Wagner, Superekslibris..., s. 51, przyp. 62.

27 K. Piekarski, Rudolf Kotula, Właściciele rękopisów i starodruków zbiorów wielkopolskich Z. Czarneckiego mieszczacych się obecnie w „Baworovianum” we Lwowie, Lwów - 1929. Recenzja, „Przegląd Biblioteczny” 1929, z. 3, s. 391, zob. też mój komentarz: A. Wagner, Superekslibris..., s. 51 , przyp. 62 . 
„metalowa matryca”, to wyciśnięty z niej jest jeden z superekslibrisów Zygmunta Augusta z 1549 r. (omawiam go na s. 299-300, il. 125). Z kolei najlepiej znanym wśród przed-XIX-wiecznych dzieł tego rodzaju jest superekslibris podwójny Aleksandra Lubomirskiego ze schyłku XVIII w., z charakterystycznym, francuskojęzycznym napisem $w$ ramce ${ }^{28}$. Druga kwestia tyczy się pojęcia „sygla", którym - w owej spolszczonej wersji - posługuję się w monografii. Recenzentka, jak widzimy na s. 458 jej tekstu, ,wolałaby sigle”. Wobec tego wypada mi oświadczyć, że taką, a nie inną, wersję tego pojęcia stosuję za kanonicznym opracowaniem pt. Paleografia łacińska autorstwa Władysława Semkowicza ${ }^{29}$. Dlatego też ja jednak wolę ,sygle”. Trzecia kwestia związana jest z pojęciami „wycisk” versus „łłoczenie”. Przesłanki przemawiające za stosowaniem w tegumentologii pierwszego z nich wyartykułowałem w monografii na s. 44. Nie przekonało to jednak Recenzentki, która przeciw „wyciskowi” wytoczyła oręż Wikipedii. W niej zaś, pod tym hasłem znalazła tylko ilustracje protezowania szczęki i ortodoncji. Przyznam, że czuję pewien niesmak posługując się podobnym kontrargumentem, kłóci się to bowiem z moim wyobrażeniem o dyskusji na łamach pisma naukowego: po wpisaniu w wyszukiwarce Google frazy „tłoczenie” otrzymujemy ,[...] powietrza/płyt/oleju” nawet „płyt winylowych", ale nie ,[...] skóry opraw”. Pragnę jednak zastrzec, że w odróżnieniu od stanowiska Recenzentki wobec „wycisku” w Wikipedii, nie uważam wyników wyszukiwania „tłoczenia” w necie za miarodajne w dyskursie oprawoznawczym. No i czwarta kwestia, dotycząca zakwalifikowania przeze mnie superekslibrisów grzbietowych jako szczególnej kategorii księgoznaków. Recenzentka uważa, że czynię to z „z niewiadomych powodów”. Otóż powód jest wiadomy, wspomina o nim także Autorka recenzji. Jest nim rzadkość tej formy superekslibrisu na staropolskich oprawach, dodajmy, że w odróżnieniu od zachodniej Europy, w której zwłaszcza w XVII-XVIII w. zyskały one sporą popularność.

Na s. 462-463 Recenzentka charakteryzuje rozdział monografii pt. Tto europejskie. Generalnie czyni to w nad wyraz rzetelny sposób. Może z jednym wyjątkiem. Otóż odnosząc się do włoskich, renesansowych superekslibrisów napisowych wykazuje poważną niekonsekwencję. Opisane i zilustrowane przeze mnie dzieła (s. 77-78, il. 9-10) zalicza bowiem „w każdym przypadku [...] do superekslibrisów, a nie tłoczeń własnościowych". Zalicza błędnie, ponieważ w każdym przypadku napisy wyciśnięte są z osobnych tłoków literowych (fot. 2a, 3a). W jednym wkomponowano je w tzw. stylizowaną mandorlę (wł. mandorla stilizzata), a w drugim w linearne, poziome ramki. Nadmienię, że

28 Wśród bogatej literatury, zob. np. S.J. Gruszczyński, O księgozbiorach i znakach bibliotecznych książą Lubomirskich w XVIII wieku, ,Roczniki Biblioteczne” 1965, t. 9, z. 1-2, s. 25, il. 10.

29 W. Semkowicz, Paleografia tacińska, Kraków 1951, s. 463-465. 
oba rozwiązania były chętnie naśladowane przez polskich introligatorów. Przykłady tego opisuję i reprodukuję w swej monografii, (s. 261, 288-290 i in., il. 96a, 118), jednak dla Autorki recenzji są one już tylko „własnościowymi tłoczeniami literowymi" (fot. 2b, 3b). Przyznam, że powyższe identyfikacyjne potknięcie Recenzentki traktuję jako spodziewaną konsekwencję pułapki, jaką następczynie M. Sipayłło (czy jak kto woli: K. Piekarskiego) zastawiły na siebie, tworząc sztywne i rygorystyczne kategoryzowanie księgoznaków. Myślę też, że dzieje się tak zawsze gdy badacz ignoruje nieobjęte bogactwo inwencji artystów i rzemieślników w każdej sferze ich twórczości: od dekoracji po technikę wykonania...

Trzy główne rozdziały monografii (Początki zjawiska (do około 1500 roku), Stulecie rozkwitu (XVI wiek) oraz Półwiecze stagnacji (pierwsza połowa $X V I I$ wieku)) Recenzentka potraktowała bardziej syntetycznie. Doceniając „bardzo szczegółowo i kompetentnie przeprowadzony wywód” jednocześnie uznała za „dość trudną w odbiorze" ${ }^{30}$ konstrukcję rozdziałów dotyczących XVI i XVII stulecia. Jako Autorowi wypada mi oczywiście uszanować taką percepcję treści książki. Zapewniam jednak, że wydzielenie dwóch okresów i znamiennych dla nich zjawisk w dwóch częściach monografii miało właśnie ułatwić czytelnikowi zobrazowanie sobie ich wszystkich. Temu też służą liczne podrozdziały, w których analizuję poszczególne, choć zwykle powiązane ze sobą, kategorie superekslibrisów. Ze smutkiem więc przyjmuję, że dla Recenzentki „może [to] być nieco męczące” ${ }^{\text {"1 }}$.

Odejdźmy jednak od ogólników. Za ciekawe i inspirujące uważam uwagi Recenzentki na temat jednego z późnogotyckich superekslibrisów Piotra Świętopełka z Zambrzecza (Ząbrca). Odniosła się ona do długotrwałych kłopotów badaczy z identyfikacją sygli „M P” i niedookreślonego znaku za literą „P”, widniejących pośrodku tego księgoznaku (fot. 4). Doświadczył ich niegdyś także K. Piekarski, najpierw identyfikując ów znak jako „S” lub Ś[więtopełk]”, z czasem jednak rezygnując z uznania trzeciego znaku za literę ${ }^{32}$. Osobiście poprzestałem na zreferowaniu stanu badań nad tą skomplikowaną kwestią. Recenzentka wypomniała mi to, proponując powrót do pierwotnej identyfikacji Piekarskiego. Przyznam, że skłoniło mnie to do bliższego przyjrzenia się owemu detalowi kompozycji księgoznaku. Doprowadziło to do konkluzji, iż na gruncie polskim u schyłku XV i 1 ćw. XVI w. taki krój jak znak w superekslibrisie miewała cyfra „3” oraz litera „Z” we wczesnej wersji kroju antykwowego. Tym samym, należałoby na nowo odczytać skróty liter z superekslibrisu jako „M[agister] P[etrus de] Z[ambrzecz]”. Dodam, że interesująco prezentują

\footnotetext{
$30 \quad$ M. Cubrzyńska-Leonarczyk, dz. cyt. s. 456.

1 Tamże.

32 Ewolucję poglądów badacza referuję w Superekslibris..., s. 125.
} 
się też spostrzeżenia Recenzentki na temat dodatkowych możliwości identyfikacji godła herbowego z domniemanego superekslibrisu Świętopełka, który w rzeczywistości jest najpewniej sygnaturą anonimowego introligatora.

Przywołany dalej przez Recenzentkę pogląd R. Marciniaka, wedle którego superekslibris Anny Jagiellonki na modlitewniku ze zbiorów BUW jest wątpliwym znakiem królowej uważam za słabo przekonujący. Autorka recenzji, podzielając opinię badacza, zwraca uwagę, że Orzeł Korony nie ma na piersi królewskiego herbu Trzy Zęby, którym pieczętował się Stefan Batory, zaś sygle „AKP” winno się odczytywać w kolejności „APK”. Na takie supozycje odpowiadam: owszem, Orzeł nie ma na piersi herbu Batorego, ponieważ Anna była z rodu Jagiellonów a Orzeł pełnił jeszcze za jej czasów rolę rodowego herbu tej dynastii (na temat złożoności funkcji herbów królewskich odsyłam do znakomitej książki Zenona Piecha ${ }^{33}$ ). Jednakowoż, nad kartuszem herbowym widnieje korona zamknięta (pałąkowa), będąca koroną królewską, a zatem predestynowaną do oznaczania superekslibrisów Anny. Dziwię się też próbie ustawienia kolejności sygli: od lewej do prawej i w górę, skoro zupełnie naturalne jest odczytywanie ich od lewej ku górze na prawo, i dalej - w dół na prawo. Taki kierunek pozwala na odczytanie skrótów jako „A[nna] $\mathrm{K}$ [rólowa] $\mathrm{P}$ [olski]”. À propos herbów i ich nazw: Recenzentka wypomina mi ,wielokrotną manierę [...] nienazywania herbu w konkretnym, omawianym superekslibrisie" ${ }^{34}$. Wobec tych słów należałoby chyba przypomnieć, że nie napisałem monografii z zakresu heraldyki, ani nawet katalogu superekslibrisów herbowych, ale przekrojowe opracowanie z zakresu kultury bibliofilskiej i sztuki. Dodam, z pewnym skrępowaniem, że owa „maniera” najwyraźniej nie przeszkadzała Jury Konkursu o Nagrodę „Studiów Źródłoznawczych" im. prof. S.K. Kuczyńskiego, przyznawanej za książki z dziedziny źródłoznawstwa i nauk pomocniczych historii. Gremium to, złożone m.in. z akademickich autorytetów w zakresie badań heraldycznych, podjęło w 2017 r. decyzję o przyznaniu mojej monografii I miejsca. Niech ten prosty fakt stanowi za dodatkową odpowiedź.

Na s. 466 Recenzentka dotyka frapującej i wciąż nierozwiązanej kwestii formuły „Frustra vivit qui nulli prodest”, którą odnotowałem w monografii jako rzadki wariant popularnej dewizy „Frustra vivit qui nemini prodest”. Nad jej religijnymi bądź pozareligijnymi źródłami zastanawiało się u nas już paru badaczy $^{35}$, w tym Elżbieta Bylinowa, która odkryła jej swobodne polskie tłumaczenie z epoki: „Prozno chowa człowieka Bóg wieczny, który sobie i ludziom nie jest pożyteczny" ${ }^{36}$. Mimo tego, powiązanie przeze mnie tych słów z Biblią

33 Z. Piech, Monety, pieczęcie i herby w systemie symboli władzy Jagiellonów, Warszawa 2003, s. 199-227, zwł. 226-227.

34 M. Cubrzyńska-Leonarczyk, dz. cyt. s. 465-467.

35 Ich teksty odnotowuję w A. Wagner, Superekslibris..., s. 279, przyp. 442.

36 E. Bylinowa, Renesansowy księgozbiór rodziny Strzemboszów, [w:] Kolekcje historyczne. 
wydaje się nietrafione, co zauważa Recenzentka. Uściślić należałoby jednak Jej sugestię, jakoby Edward Różycki ograniczył się tylko do podania informacji o zagadkowej, pierwszej wersji dewizy: otóż ów wytrawny badacz ją podał, bazując na znanym z autopsji egzemplarzu superekslibrisu, zaś na tabl. V/il. 4 zamieścił jego przyzwoitą reprodukcję ${ }^{37}$. Nie pozostawia to wątpliwości (zdaje się, że ma je Recenzentka), co do istnienia takiego wariantu dewizy. Kontynuując wątek napisów i ich skrótów, Autorka recenzji odnosi się do chrystogramu "IHS" upowszechnionego na introligatorskich plakietach medalionowych pod koniec XVI w. Słusznie stwierdza, że oznaczano nim książki przede wszystkim pobożnych bibliofilów doby kontrreformacji, a nie tylko księgi jezuickie. Tą samą prawidłowość akcentuję wyraźnie na s. 344-345 monografii.

W sumie drobna, ale warta odnotowania, rozbieżność między mną a Recenzentką tyczy się stosunku do tzw. „opraw mniszych” versus „opraw półskórkowych na deskach lub tekturze". Autorka recenzji hołduje starej-można by rzec: romantycznej - nazwie „oprawy mnisze” mimo że z kulturą monastyczną oraz mnichami XV i XVI w. nie miały one właściwie nic wspólnego. Miały za to wiele wspólnego z nieszczególnie zamożnymi kręgami akademickimi, wśród których ten właśnie sposób oprawiania ksiąg był popularny, a może wręcz bardzo popularny (przed stanowczym sądem powstrzymuje mnie brak badań statystycznych). Co więcej, stając się niejako synonimem akademickiego bibliofilstwa, takie oprawy zaczęły być zamawiane przez bibliofilów-bogaczy, że wspomnę o rozmiłowanym w przepychu kanclerzu Krzysztofie Szydłowieckim. I jeszcze jedno: skoro upierać się przy pojęciu „oprawa mnisza”, tam, gdzie skóra zachodzi z grzbietu na około połowę szerokości gołych desek okładzin, to jak nazywać - upowszechniające się w XVI w. - oprawy ze skórą zachodzącą w taki sam sposób na tekturę (czasem obleczoną makulaturowym pergaminem)? Recenzentka nie daje swej propozycji nazewniczej, zatem robię to tutaj: półskórek na tekturze (z zaznaczeniem, że chodzi o oprawę z XVI w., co zapobiega skojarzeniu takiego dzieła z półskórkami z XVII-XXI w.). Oczywiście, nie znaczy to bym postulował zupełne wyrugowanie z polszczyzny omawianego pojęcia; za pożądane uważam jednak zapisywanie - i traktowanie - go w cudzysłowie.

Śledząc dalej treść monografii Recenzentka przygląda się kolejnym rozdziałom: Superekslibris a sztuki plastyczne oraz Zagadnienia techniczne i organizacyjne. $\mathrm{Z}$ większością zawartych względem nich spostrzeżeń się zgadzam, inne - mimo nieco innego wejrzenia - szanuję. Rezygnuję więc z dodania czegokolwiek od siebie.

Księgozbiory szlacheckie XVI-XVII wieku, Warszawa 2004, s. 36, przyp. 128

37 E. Różycki, Oprawy ksiag archiwalnych źródtem do historii bibliofilstwa (na przykładzie b..Województw Podolskiego oraz Ruskiego Rzeczypospolitej), „Roczniki Biblioteczne” 1978, t. 22, z. 3-4, s. 441, tabl. V/il. 4. 
Na koniec zatem wypadałoby podziękować Recenzentce za skrupulatne odnotowanie chochlików drukarskich i zwyczajnych lapsusów. Jak to się stało, że w podpisie pod ilustracją ekslibrisu Chodkiewiczów, którego tuż obok fotografii opisuję w tekście, znalazło się nazwisko Sapiehów...zachodzę w głowę, ale i tak nie mam pojęcia(!). Podobnie jak wzmiankowanie ogólnie znanego superekslibrisu Franciszka Podoskiego jako superekslibrisu Franciszka Bielińskiego oraz przeistoczenie się „Librariae” w „Liberiae”. Pozostaje mi chyba cieszyć się, że jak na prawie 600 stron książki, w tym około 300 fotografii i tablic, statystyka powyższych potknięć (zapewne znalazłoby się ich więcej) wygląda chyba nie najgorzej. Jeszcze jedna, wciąż trudna dla mnie, sprawa wymagałaby słowa komentarza. Recenzentka, w dość dosadny sposób, wytyka Wydawnictwu Naukowemu UMK opublikowanie książki wprawdzie na grubym i ładnym papierze, ale jako woluminu klejonego a nie szytego. To, co piszę dalej, jest doskonale znane każdemu tzw. młodszemu pracownikowi naukowemu polskich uczelni: jako osoba sprowadzana przez „system” do pozycji petenta w takimż wydawnictwie, musiałem się cieszyć, że w ogóle dano mi do wyboru książkę full color - ale klejoną lub zgrabnie szytą - ale czarno-białą. Wybrałem to drugie...nie negocjując. Bo gdy habilitant z uczelnianym wydawnictwem negocjuje, zwracając uwagę na to, co odkryła Recenzentka, to słyszy sakramentalne: „,proszę drukować za własne pieniądze gdzie indziej”.

Zamykając ów zbiór refleksji po lekturze artykułu recenzyjnego $\mathrm{M}$. Cubrzyńskiej-Leonarczyk muszę stwierdzić, iż cenię sobie możliwość podjęcia dyskusji z badaczką, której dorobek stanowił dla mnie jedną z inspiracji do napisania monografii staropolskiego superekslibrisu. Mimo iż meritum oraz sposób formułowania uwag Recenzentki niejednokrotnie wzbudził mój sprzeciw i prowadził do repliki, to jednocześnie samą ideę krytycznej dyskusji na łamach niniejszego periodyku uważam za wielce wzbogacającą. W niej bowiem upatruję przejaw dojrzałego dyskursu badawczego, prowadzącego do konstruktywnych wniosków, a w rezultacie - do rozwoju nauki. Piszę to ze szczerym przekonaniem, ponieważ w bibliologii (nie mówiąc o innych dziedzinach humanistyki) odnotowuję coraz więcej recenzji, które z krytyczną dyskusją nie mają nic wspólnego, a trącą płytkim panegiryzmem. Powodów tego stanu rzeczy jest zapewne wiele. Wśród nich odnotowałbym jednak zagęszczającą się sieć wzajemnych zależności między pracownikami akademickimi z różnych ośrodków. Te zaś coraz częściej nakazują pisanie asekuracyjne i pochlebcze, bo przecież nieukontentowany interlokutor może być kiedyś anonimowym recenzentem wniosku o projekt badawczy. Między Recenzentką i mną nie ma takich potencjalnych zależności. Owocem tego stała się niniejsza dyskusja. Głęboko wierzę, że interesująca również dla jej świadków. 


\section{Wybór bibliografii i źródeł \\ (obejmuje wyłącznie publikacje wymienione w przypisach)}

Źródło

Szymon Starowolski, Kazanie wtore o nowym oswieciniu świata przez Marya, iako przez księge iaka cudownie pisana, [w:] tegoż, Swiatnica Panska Zamykająca w sobie Kazania Na Vroczystosci Swiąt Całego Rokv..., Kraków 1645.

Publikacje

Biesiadecki F., Piekarski K., Materjały do dziejów biblioteki Zygmunta Augusta. Serja I, „Exlibris” 1924, t. 5, s. 38-48.

Bylinowa E., Renesansowy księgozbiór rodziny Strzemboszów, [w:] Kolekcje historyczne. Ksiegozbiory szlacheckie XVI-XVII wieku, Warszawa 2004, s. 17-105.

Encyklopedia Wiedzy o Ksiażce, red. zbiorowa, Wrocław-Warszawa-Kraków 1971.

Gruszczyński S.J., O księgozbiorach i znakach bibliotecznych książat Lubomirskich w XVIII wieku, „Roczniki Biblioteczne” 1965, t. 9, z. 1-2, s. 375-386.

Komza M., Maria Cubrzyńska-Leonarczyk, Polskie superekslibrisy XVI-XVIII wieku $w$ zbiorach Biblioteki Uniwersyteckiej w Warszawie. Centuria druga, Warszawa: Biblioteka Narodowa, 2001 [...] - Recenzja, „Roczniki Biblioteczne” 2001, t. 45, s. 298-302.

Piech Z., Monety, pieczęcie $i$ herby w systemie symboli władzy Jagiellonów, Warszawa 2003.

Piekarski K., Ksiązka w Polsce XV i XVI wieku, [w:] Kultura staropolska, Kraków 1932, s. 352-384.

Piekarski K., O superexlibrisie polskim, [w:] Katalog wystawy pięknej książki polskiej urzadzonej z powodu IV. Zjazdu Bibliotekarzy Polskich w Warszawie, 31 maja - 15 czerwca, Warszawa 1936, s. 29-31.

Piekarski K., Rudolf Kotula, Właściciele rękopisów i starodruków zbiorów wielkopolskich Z. Czarneckiego mieszczacych się obecnie w „Baworovianum” we Lwowie, Lwów 1929. Recenzja, „Przegląd Biblioteczny” 1929, t. 3, z. 3, s. 388-415.

Piekarski K., Superexlibrisy polskie od XV do XVIII wieku. Z. 1, Kraków 1929.

Różycki E., Oprawy ksiag archiwalnych źródłem do historii bibliofilstwa (na przykładzie

b. Województw Podolskiego oraz Ruskiego Rzeczypospolitej), „Roczniki Biblioteczne” 1978, t. 22, z. 3-4, s. 423-452.

Semkowicz W., Paleografia łacińska, Kraków 1951.

Sipayłło M., O metodzie badań proweniencyjnych starych druków, „Z Badań nad Polskimi Księgozbiorami Historycznymi” 1975, z. 1, s. 9-30. 
Wagner A., Ekslibris jako dziedzina grafiki w sferze zainteresowania historii sztuki i bibliologii, [w:] Metodologia, metoda i terminologia grafiki i rysunku. Teoria i praktyka, red. J. Talbierska, Warszawa 2014, s. 95-105.

Wagner A., Superekslibris polski. Studium o kulturze bibliofilskiej i sztuce od średniowiecza do połowy XVII wieku, Torun 2016.

Fot. 1a. Przykład superekslibrisu napisowego w sąsiedztwie wycisku plakiety z wizerunkiem personifikacji, introligator anonimowy, prawdopodobnie Torun, 1573. Źródło: zbiory W. B. P - Książnicy Kopernikańskiej w Toruniu.

\section{Zdjęcie: A. Wagner}

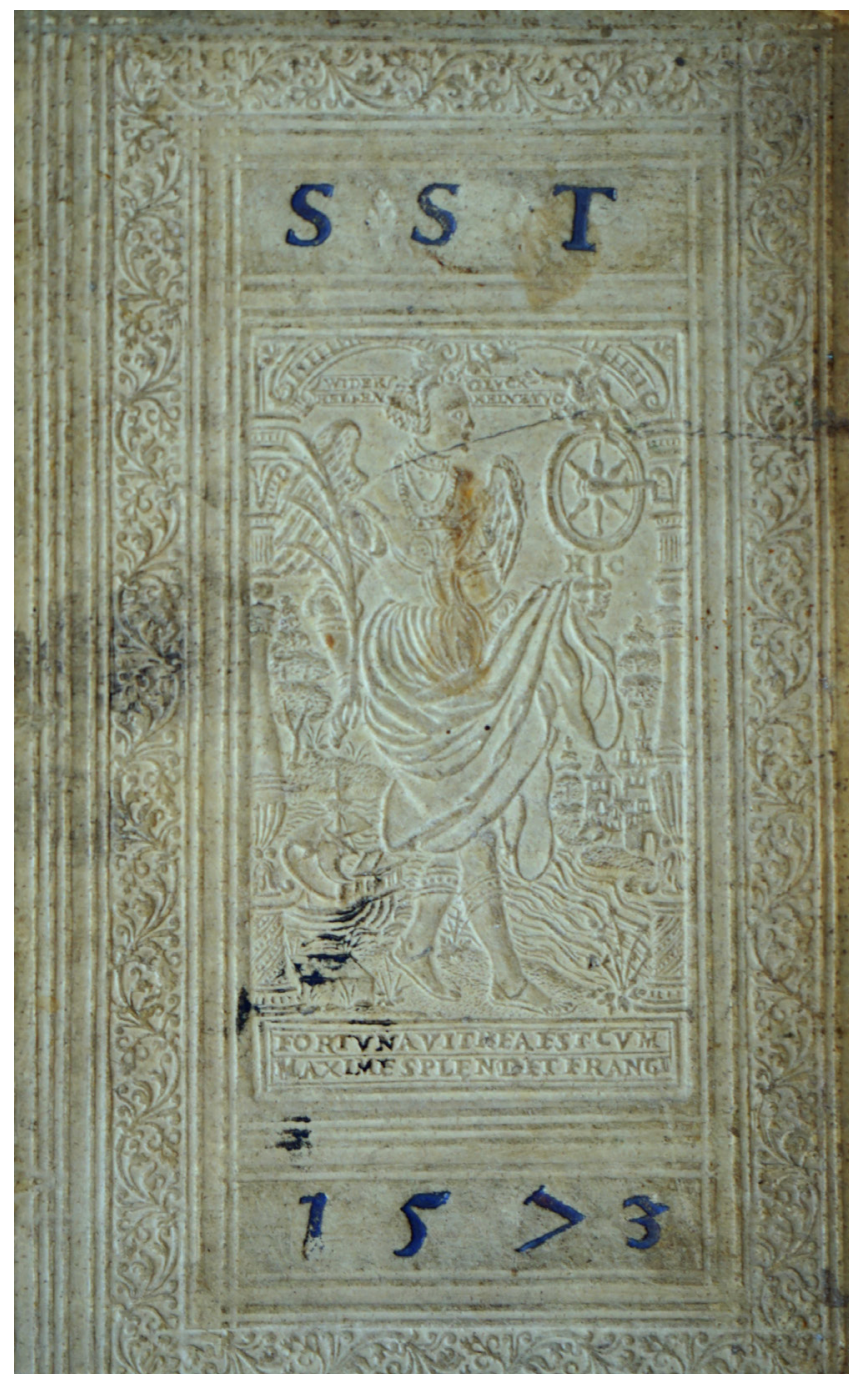


Fot. 1b. Przykład superekslibrisu napisowego i superekslibrisu herbowego jednego bibliofila, introligator anonimowy, prawdopodobnie Gdańsk 1565. Źródło: zbiory W. B. P - Książnicy Kopernikańskiej w Toruniu. Zdjęcie: A. Wagner

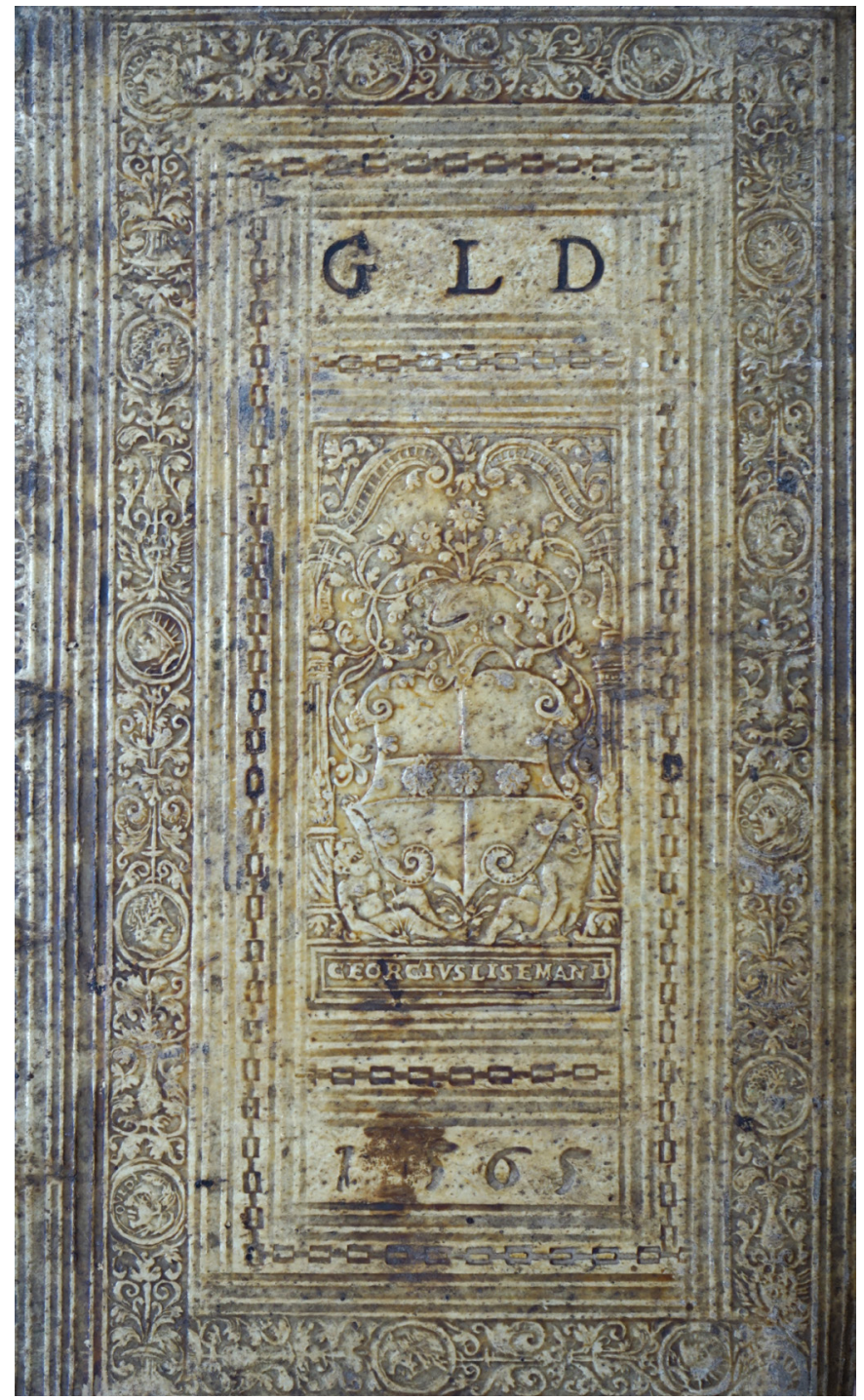


Fot. 2a-b. Porównanie superekslibrisów napisowych na: a) oprawie włoskiej z 1. 20. XVI w. oraz b) oprawie polskiej z 1. 30. XVI w. Źródło: A. Wagner, Superekslibris polski. Studium o kulturze bibliofilskiej i sztuce od średniowiecza do połowy XVII wieku, Toruń 2016, il. 9, 9a
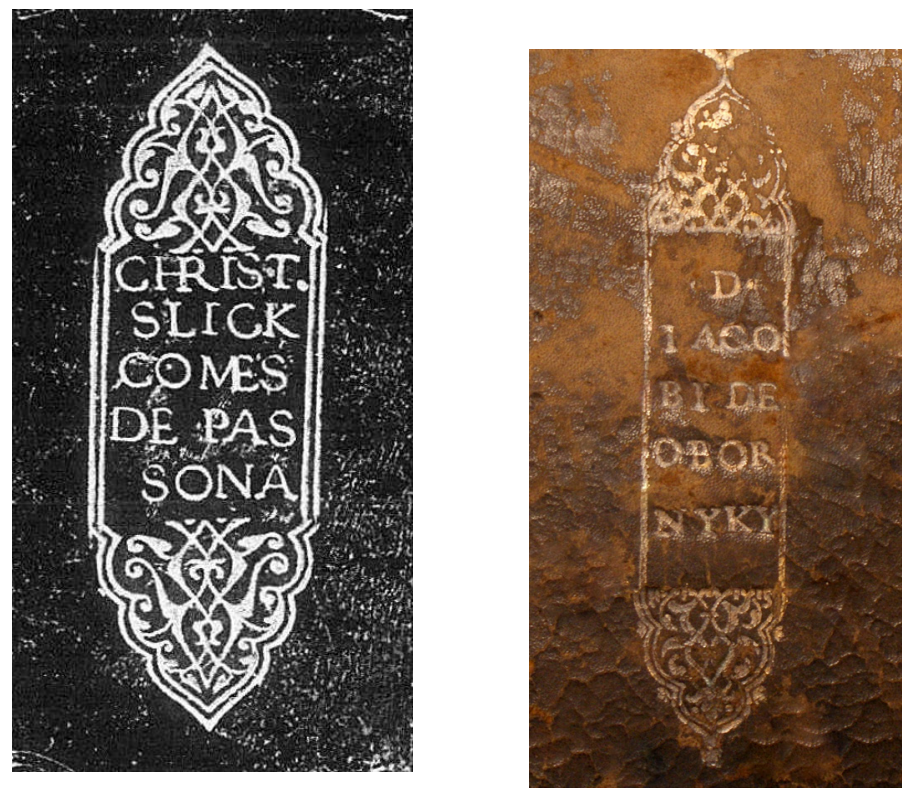

Fot. 3a-b. Porównanie superekslibrisów napisowych na: a) oprawie włoskiej z 1530 r., oraz b) oprawie polskiej z 1526 r. Źródło: A. Wagner, Superekslibris polski. Studium o kulturze bibliofilskiej i sztuce od średniowiecza do połowy XVII wieku, Toruń 2016, il. 9, 9a., il. 10, 118
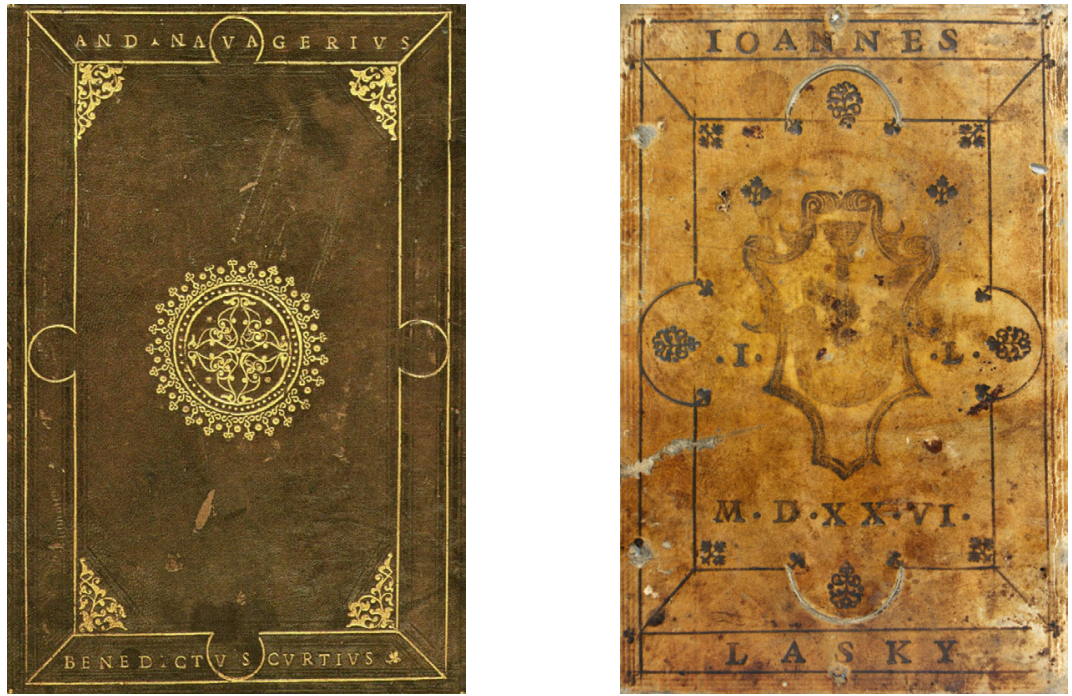
Fot. 4. Superekslibris I Piotra Świętopełka z Zambrzecza, introligator anonimowy, Kraków 1481, zbiory Biblioteki Jagiellońskiej. Źródło: A. Wagner, Superekslibris polski. Studium o kulturze bibliofilskiej i sztuce od średniowiecza do połowy XVII wieku, Toruń 2016, il. 37.

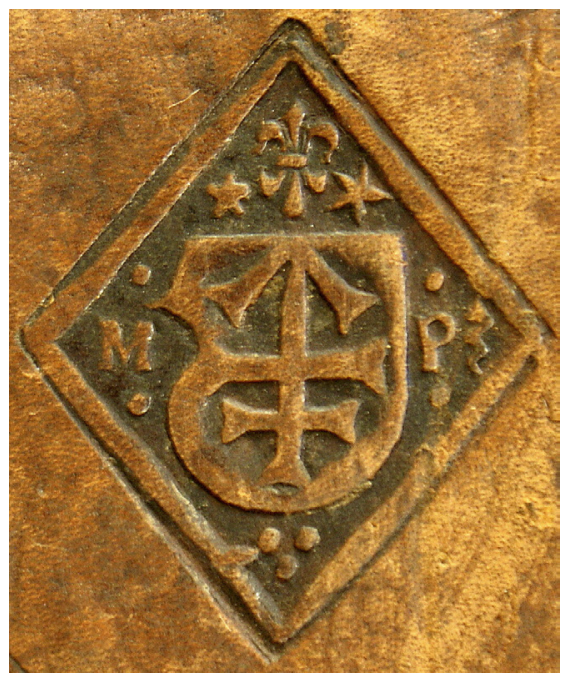

